\title{
Thirty years with Flora Croatica database
}

\author{
TONI NIKOLIĆ
}

University of Zagreb, Faculty of Science, Division of Biology, Department of Botany, Maruliceev trg 9a, HR-10000 Zagreb, Croatia

*Autor za dopisivanje / corresponding author: toni.nikolic@biol.pmf.hr

Tip članka / article type: stručno priopćenje / professional communication

Povijest članka / article history: primljeno / received: 14.11.2020., prihvaćeno / accepted: 23.12.2020.

URL: https://doi.org/10.46232/glashbod.8.2.4

Nikolić, T. (2020): Thirty years with Flora Croatica database. Glas. Hrvat. bot. druš. 8(2): 94-107.

\section{Abstract}

The Flora Croatica (FCD) database records thirty years of continuous work these days. Since the initial limited application, today FCD has been nationally and internationally recognized as the relevant source of verified data on national and regional flora. It is fully web oriented with the strong support of GIS tools in spatial data display and analysis. Users are a wide range of individuals, public institutions, museums, educational system institutions, scientific institutions, and private companies. With numerous interconnected modules, it enables the processing and presentation of various data on flora - taxonomy, nomenclature, distribution, threat status, use, invasiveness, bibliography, collections, etc. Website monitoring indicates great dynamics of data entry, processing, and use, as well as international cooperation. Further development of FCD and application of modern IT tools in the best possible support to all classes of users is expected, both in quantitative and qualitative terms.

Keywords: development, flora, Flora Croatica Database, history, usage

Nikolić, T. (2020): Trideset godina s bazom podataka Flora Croatica. Glas. Hrvat. bot. druš. 8(2): 94-107.

\section{Sažetak}

Baza podataka Flora Croatica (FCD) bilježi ovih dana trideset godina neprekidnog rada. Od početne ograničene primjene, danas je FCD nacionalno i internacionalno prepoznat kao relevantni izvor provjerenih podataka o nacionalnoj i regionalnoj flori. U cijelosti je web-orijentirana sa snažnom podrškom GIS alata u prikazu i analizi prostornih podataka. Korisnici su široka paleta pojedinaca, javne ustanove, muzeji, ustanove obrazovnog sustava, znanstvene ustanove i privatne tvrtke. $S$ brojnim uzajamno povezanim modulima omogućuje obradu i prikaz raznorodnih podataka o flori - taksonomiju, nomenklaturu, rasprostranjenost, ugroženost, upotrebu, invazivnost, bibliografiju, zbirke i dr. Praćenje prometa ukazuje na veliku dinamiku unosa, obrade i upotrebe podataka, te međunarodnu suradnju. Očekivani je daljni razvoj FCD-a i primjena modernih IT alata u što kvalitetnijoj podršci svim klasama korisnika, u kvantitativnom i kvalitativnom pogledu.

Ključne riječi: flora, Flora Croatica baza podataka, povijest, razvoj, upotreba 


\section{Introduction}

The monitoring and analysis of biodiversity requires the use of large amounts of different data. Most often it is data related to taxonomy and nomenclature and data on the distribution of individual taxonomic units, although the total spectrum of required data is incomparably wider. IT tools in processing biodiversity data was therefore natural and fast. The statement "The impacts of electronic data processing in the various fields of taxonomy and systematic ..., come to be looked upon, in retrospect, as one of the most curious episodes in the history of biology" (Heywood 1984) nowadays seems to be true. To facilitate data exchange, the International Working Group on Taxonomic Databases in the Plant Sciences (TDWG) has attempted to establish standards for various data elements in plant taxonomic work. A comprehensive information model for the taxonomic data recording was devised for the Global Plant Checklist database project of the International Organization of Plant Information (IOPI) (Berendsohn 1997). Since the beginnings of this dynamic field (reviews for instance Crovello \& MacDonald 1974, Jury 1991, Ball-Damerow et al. 2019), tire bioinformatics has today "become a major growth industry almost in its own right" (Sugden \& Pennisi 2000).

As highlighted in Ball-Damerow et al. (2019), online databases with detailed information on organism occurrences collectively contain well over one billion records, and the numbers continue to grow. The digitization of natural history specimens (Beaman et al. 2012) and development of online platforms for citizen science (Sullivan et al. 2014) have driven a steady accumulation of records on the occurrence of species over the last decade. For example of this growth is the Global Biodiversity Information Facility (GBIF), which has grown from just over 200 million records in 2010 to over 1.08 billion records today, a more than fivefold increase. The number of national and regional databases is really large, as is the number of global pooling initiatives into super systems.

On the local scene, i.e. for the territory of the Republic of Croatia, this global trend has its own copy, at least when it comes to vascular flora, as the main component of total biodiversity. Flora Croatica Database (FCD) is a national database with a thirty-year tradition (Nikolić 2005-onwards). Since its beginnings and local application, the FCD has become an internationally recognized source of various types of verified data with up to one million queries per year and up to 400 users per day. Since 2005, with minor interruptions, FCD has been an integral part of the Nature Protection Information System of the Republic of Croatia (ISZP), today under the storm of the Ministry of Economy and Sustainable Development (Institute for Environment and Nature ).

\section{Users}

FCD users are numerous individuals of a wide age and educational profile, but also legal entities from the public and private sector. From the public sector, these are primarily state institutions (e.g. Ministry of Economy and Sustainable Development), former and current specialized agencies (e.g. State Institute for Nature Protection, Croatian Environment and Nature Agencies, Environmental Protection and Energy Efficiency Fund, Croatian Waters), public institutions (nature parks, national parks, county public institution for nature protection), natural history museums, non-governmental associations, numerous institutions from the educational sector (schools and faculties) and scientific institutions (faculties and institutes). From the private sector, these are mainly companies performers of environmental impact studies. 


\section{Purposes}

The original FCD purposes are defined when designing the project and have remained the same to this day. Based on the activities carried out, these are:

- profession: (1) area of nature protection and biodiversity, (2) spatial planning, (3) environmental impact studies, (4) legislation, (5) monitoring of changes (monitoring), (6) maintenance of natural history collections, (7) fulfilment of international obligations, (8) implementation of projects and (9) other;

- science: an indispensable source of data in scientific research, in particular flora, biogeography, and ecology, but also other disciplines of the wider field of botany. Measurable is the application of FCD in the implementation of domestic and international scientific projects, as well as in the preparation of graduate papers, and master's and doctoral dissertations;

- education: application in the implementation of curricula especially of higher education institutions, but also during secondary school education;

- popularization: of national flora and biodiversity on a wide platform, both on the domestic and international scene.

\section{Copyrights}

FCD is the property of the Faculty of Science, University of Zagreb (PMF). Copyright on IT solutions is equally shared by the Faculty of Electrical Engineering and Computing, University of Zagreb (FER).

The copyrights on the data are diverse:

- individuals use FCD as a resource to store, process and publish their own original data. Individuals are always the author of their data regardless of the availability thereof. Data owners decide in their own discretion on their availability:
- public data of individuals:

- funded by their own resources are available to the public in the form of a Creative Commons license BY-NC-SA, i.e. mandatory attribution (quoting authors), non-commercial use, possible derivative use (e.g. scientific papers), and possible re-distribution under the original conditions

- funded by public funds are available to the public in the form of a Creative Commons license BY-SA, i.e. mandatory attribution (quoting authors), and possible re-distribution under the original conditions

- non-public data is visible only to the author, and the data owner for a period of up to three years, after which it becomes part of the previous CC license BY-NC-SA

- Legal entities use FCD as a resource to store, process and publish their own original data:

- public data is all data whose collection is financed by public funds, is available to the public in the form of a Creative Commons license BY-SA, i.e. mandatory attribution (quoting authors or editors) and possible re-distribution under the original conditions. A legal entity decides whether the attribution is related to an employee, editor or legal entity.

- non-public data is visible only to authorized legal entity for a period of up to three years, after which it becomes part of the previous CC license BY-NC-SA

\section{History}

The roots of FCD development (originally CROFlora) date back to the early 1990s, just 10 years after the advent of the first PC computers, during the time of the Gopher protocol and the earliest stages of the World Wide Web. In terms of databases, this is the time of Borland's Paradox and dBase, Fox's FoxPro, and the first version of MS Access. 
In botanical terms, the first need to store and process a larger amount of data has arisen from the monographic processing of the genus Thalictrum (Ranunculaceae). This work has generated an abundance of scientific names within the genus at national and regional levels with a number of necessary accompanying attributes (synonyms, authorization, bibliography, photo documentation, etc.). The first conceptually amateur gender database was created in dBase IV, then converted to Access v2.0 for Microsoft Windows v3.1.

However, in the early 1990s, a parallel initiative began on the development of the Index Florae Croaticae by the group of authors, which was then successively published (Nikolić 1994, 1997, 2000). A manifold larger amount of collected data and the need for its almost daily use and updating inevitably led to a combination with previous experience in working with databases. The idea of processing the national vascular flora with a specialized database is formalized by a project financed by the Ministry of Science and Technology - Biological Database and GIS (1993 - 1996), and its eponymous continuation (1996 - 1999). These projects enabled cooperation with the professional IT sector, initially unsuccessfully with private companies, and then with the Faculty of Electrical Engineering and Computing of the University of Zagreb (Department of Applied Computing) in a collaboration that continues to this day.

In the following period, the funds for work and development were met with target development projects, but perhaps to a greater extent part of the projects mainly from other goals, in the realization of which, on the one hand, stood PMF, and on the other numerous domestic and international investors. These are i-project Useful Herbs of Croatia (Ministry of Science and Technology, 2003 - 2004), online access to CroFlora database (State Institute for Nature Protection of the Republic of Croatia, 2004), Inventory of flora for the needs of the project Conservation of Karst Ecological Systems (Ministry of Environmental Protection and Physical Planning,
GEF Funds - Global Environmental Facility, 2004 - 2006), Flora Croatica Database (Environmental Protection and Energy Efficiency Fund, 2005 2007), Database on Invasive Taxa of Croatian Flora (State Institute for Nature Protection, 2005 - 2007), Biodiversity of vascular flora of the Adriatic area (Ministry of Science of Education and Sports, 2007 - 2010), Important Plant Areas Project in Croatia (PlantLife \& BBI-MATRA 2005 - 2008), Countdown towards 2010 in Zagreb: community involvement in biodiversity assessment (ECNC-European Centre for Nature Conservation, 2006), Distribution and ecological profiles of invasive plants (University of Zagreb, 2015 - 2018), Inventory of Croatian moss (HBoD and NIP project of the State Institute for Nature Protection, 2014 - 2015), Establishment of a national system for monitoring invasive alien species (Croatian Agency for Environment and Nature, 2018), and finally the Agreement on Co-financing the work and development of the FCD (Ministry of Environmental Protection and Energy, 2020 - 2023).

The estimated total investment in the FCD, the most significant is in-kind investment of the parent institution in the form of invested time of numerous employees and logistics, and then a difficult to measure but huge contribution of external associates.

\section{International cooperation}

From the beginning, there was international collaboration, which greatly accelerated the initial development of FCD. The first data stored in the database were collected from several sources. Nomenclature and related data that form a basic list of about 12000 taxa originate from the database for middle Europe FLOREIN 4.1 (Interaktives Programm zur Bearbeitung floristischer Daten, Zentralstelle für die Floristische Kartierung Deutschlands) (Anonymous 1995), which was used after the publisher's approval. The genera names were checked out by comparing with Names in Current Use in digital version (Greuter et al. 1993, by courtesy of the author) and with family and genera list from digital version of Flora 
Europaea Database, which is part of the PANDORA taxonomic database system at the Royal Botanic Garden Edinburgh (by courtesy of R. Pankhurst). The data on the authors of scientific names is stored according to Brummitt \& Powell (1992) obtained in digital form by kindness of authors. Ecological parameters were obtained on a commercial basis from Verlag Erich Goltz Goltze / Co. KG, as a part of database SCRIPTA GEOBOTANICA XVIII Datenbank V1.4. (Zeigewerte von Pflanzen in Mitteleuropa), and additionaly the part of data was imported from database PHANART ver. 10 and PHANSYS (Datenbank der Gefäss- pflanzen Mitteleuropas, Bern) (Lindacher 1995, by kindness of the author). Most of the journal title abbreviations were partly imported from previously used database LITFAS 2.2 (Zentralstelle für die Floristische Kartierung Deutschlands).

Today, international cooperation is achieved primarily through the availability of FCD data in the preparation of scientific papers, master's and doctoral thesis, and for the purpose of implementing international projects.

\section{Structure and modules}

Several scientific contributions have been published on the original concept and interior architecture of FCD (Fertalj et al. 2000a, Nikolić et al. 2001, Milašinović et al. 2013), expert contributions (Nikolić \& Milašinović 2014, Nikolić et al. 2014) and congress announcements (Fertalj et al. 2000b, Mihelj et al. 2007, Milašinović et al. 2012), so these contents will not be repeated here. In addition to the numerous modifications that occurred after these publications (Štimac 2012, Đurašević 2016, Perović 2016, Kraljević 2017, unpublished interventions), FCD currently consists of several closely connected modules:

Taxonomy and nomenclature. The basic module of FCD contains the taxonomic tree of the vascular and non-vascular flora of Croatia with a total of 13 subclasses and a sequential classification system according to APG - Angiosperm Phylogeny Group
(2009, 2016), to the level of subspecies. The basis of the construction of the national census was Index Florae Croaticae (Nikolić 1994, 1997, 2000), which in the later period was continuously upgraded in accordance with new findings. Currently, the classification tree contains 18 superorders, 56 orders, 189 families, 1095 genera, and 5054 species and subspecies of vascular flora. It also contains 93 families, 254 genera with 795 species and subspecies of non-vascular flora. In addition to the taxonomic tree is a wide range of accompanying data - synonyms, authorization, galleries, descriptions, ecological indices, folk names, data on findings from multiple sources, etc.

Red book. Online data on the endangerment of the vascular flora of Croatia based on the edition of Nikolić \& Topić (2005) with several additions in the later period. The idea of this module is to keep the endangerment data permanently up-to-date and easily accessible, without the need for a relatively rare production of the most commonly expensive print editions.

Bibliography. Catalog of publications of all types on flora and vegetation of the Republic of Croatia, currently with about 9000 input units, domestic and foreign authors with partial input and lists of species and their findings, if they contain.

Useful plants. Economic botany module is based on the standard for economic botany and accumulation of data from numerous thematic sources. Economic Botany Data Collection Standard of TDWG was used to typify the use method, according to Cook (1995). A summed-up view of the actual and potential use of national vascular flora, as well as a list of numerous data sources, was given in Nikolić \& Rešetnik (2007) and Nikolić (2020a).

Allochthonous plants. Module intended for monitoring the condition of allochthonous flora based on the national classification system (Mitić et al. 2008) with special emphasis on invasive flora with an initial list of invasive species based on Boršić et al. (2008), later upgraded. 
Mosses. The most recent module introduced in 2018 is intended for processing non-vascular flora, i.e. subclass Anthocerotidae Engl., Bryidae Engl. and Marchantiidae Engl. with the same attribute approach as for vascular flora.

Gallery. Cumulative collection of all photographs of the FCD (from natural habitats and herbarium collections) and habitats with almost 157000 contributions at the time of writing this manuscript.

Habitats. Module intended for processing habitat types following the National Classification System (Antonić et al. 2005) with descriptions, active taxon lists, photo documentation, conversions to other classification systems (EUNIS, Corine Landcover, and NATURA 2000), etc.

Families. Module in which DELTA system is integrated (Dallwitz et al. 1993, 1999, 2000 onwards) and which enables (1) generation of family descriptions, (2) creation of tables of differences or similarities between selected families, and (3) multiple keys for determining families. The results are generated for now in English (translation of parts of bases not Croatian is in progress)

Observations. Module intended for storage and processing of original field observations of individuals and firms with georeferencing.

Collections. Module intended for professional processing of herbarium collections with a set of accompanying data, currently using collections ZA, ZAHO (Faculty of Science, Zagreb), NHPM (Croatian Museum of Natural History, Zagreb), ZAGR (Faculty of Agriculture, Zagreb) and to a lesser extent NHMS (Natural History Museum, Split).

Diversity analysis. A complex analytical module that enables (1) the production of ecological profiles based on a series of abiotic inputs and distribution data, (2) data frequency analysis, (3) a series of specific analyses of biodiversity and its spatial distribution, (4) the management of spatial themes, all with selective types of reports including GIS formats.
Statistical analysis. Analysis of floristic lists with respect to numerous criteria (life forms, endemism, endangerment, etc.) as an option that is available whenever the result of the search is a list of taxa.

\section{Spatial data and cartographic representations.}

Spatial data is one of the most important and sought-after types of FCD data. They are generated (1) by geocoding the findings of taxa (herbariums, field observations, literature reports, georeferenced photographs), (2) digital cartographic content as available GIS themes. Georeferences can be entered in a variety of systems, including system-to-system conversions. Access to spatial data is provided in different FCD modules, and cartographic representations are possible through MapServer and FCD Geoportal, along with spatial data originating from other sources (State Geodetic Administration, Ministry of Environmental Protection and Energy, foreign public cartographic services).

\section{IT background}

In the dynamic world of IT technologies and thirty years of development, it is to be expected that the itinerary of FCD will be subject to constant modifications of all components. Not all details of the numerous adjustments were recorded, especially during the first years of development when these modifications were not considered important for monitoring.

Currently, FCD consists of 175 tables, 245 views, 19 functions, and 777 procedures. Since 2004, FCD has had an bilingual internet interface (URL https://hirc. botanic.hr/fcd/). The initial review of the species has been written using ASP.NET WebForms technology, and then a red book, bibliography, useful herbs, observations, and habitats were added with the same technology. The herbarium collection processing and diversity analysis are made with ASP.NET MVC, and the diversity calculation uses Windows Workflow Foundation services to define the steps of the complex calculation process. In order to allow FCD to span across different applications 
and servers, Single Sign-on application has been developed using Identity Server 4. New modules, as the gallery module, administrator module, and herbarium editing module are written in NET Core. There is a tendency to upgrade old modules from deprecated WebForms to .NET Core. Besides custom developed applications, FCD uses GeoServer and MapServer to display spatial data on Geoportal and publish data to external users using WFS and WMS.

a)

\begin{tabular}{|c|c|c|}
\hline Users & total registered users & 376 \\
\hline \multirow[t]{5}{*}{ Taxonomy } & $\begin{array}{l}\text { number of species and } \\
\text { subspecies }\end{array}$ & 5849 \\
\hline & number of genera & 1349 \\
\hline & number of families & 282 \\
\hline & synonyms & 20086 \\
\hline & vernacular names & 16493 \\
\hline \multirow[t]{3}{*}{ Authors } & authors of taxa names & 30407 \\
\hline & used authors of taxa names & 2198 \\
\hline & authors of other data & 5437 \\
\hline \multirow[t]{3}{*}{ Geocoding } & coordinates & 146824 \\
\hline & used coordinates & 98676 \\
\hline & geocoded findings & 958032 \\
\hline \multirow[t]{5}{*}{ Photodocumentation } & photos & 156901 \\
\hline & taxa with photos & 5638 \\
\hline & habitats with photos & 532 \\
\hline & geocoded photos & 11277 \\
\hline & authors of photos & 203 \\
\hline \multirow[t]{2}{*}{ Observation } & $\begin{array}{l}\text { field observations } \\
\text { geocoded findings from } \\
\text { observations }\end{array}$ & $\begin{array}{l}62828 \\
541061\end{array}$ \\
\hline & $\begin{array}{l}\text { geocoded taxa from } \\
\text { observations }\end{array}$ & 3999 \\
\hline \multirow[t]{5}{*}{ Herbariums } & herbarium specimens & 55083 \\
\hline & $\begin{array}{l}\text { geocoded finding from } \\
\text { herbariums }\end{array}$ & 46820 \\
\hline & geocoded taxa from herbariums & 4191 \\
\hline & scaned herbarium specimens & 27265 \\
\hline & number of collections in FCD & 22 \\
\hline \multirow[t]{3}{*}{ Bilbiography } & number of reference & 12448 \\
\hline & geocoded taxa from references & 5406 \\
\hline & $\begin{array}{l}\text { geocoded findings from } \\
\text { references }\end{array}$ & 358874 \\
\hline \multirow[t]{2}{*}{ Habitats } & species-habitat relations & 3569 \\
\hline & habitats & 1331 \\
\hline
\end{tabular}

The hardware was successively restored, both its worn-out components and entire computers. The same applies to peripheral equipment, back-up units, UPS devices, etc. Today, FCD operates on two servers (hirc.botanic.hr and visiani.botanic. hr) with multiple independent Synology backup units with an optical connection to the outside.

b)

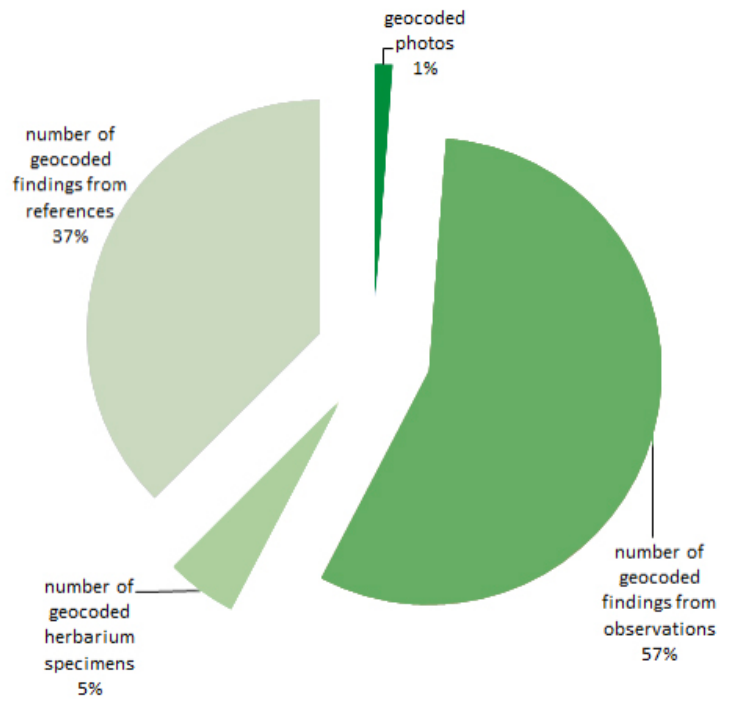

c)

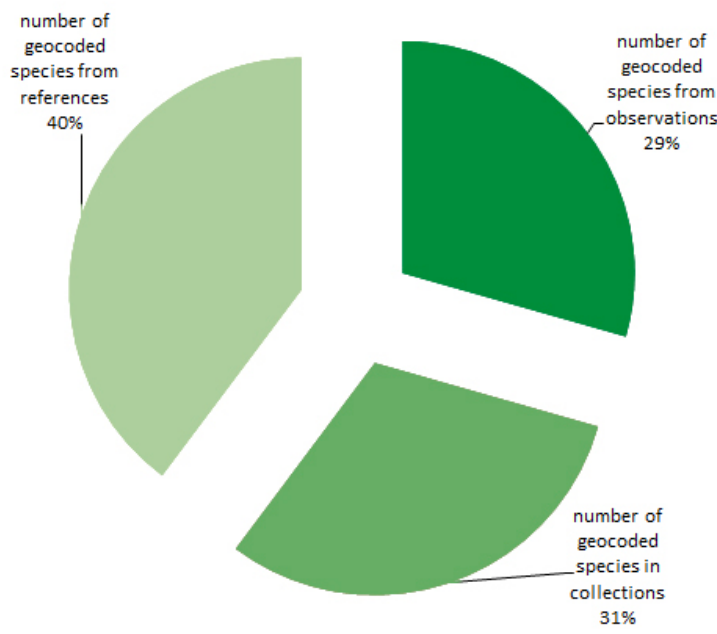

Figure 1. Overview of FCD data amounts: according to the main data categories (a), number of geocoded findings form different sources (b), number of geocoded taxa from different sources (c). 


\section{Data}

The current data status of the main FCD items at the time of writing this manuscript (November 2020) is shown in Fig. 1a. Without intending to repeat the data presented here, several facts should be further explained. The total number of registered users is not equal to the number of active users. Namely, individuals completely legitimately renew access to their needs, so the number of active users is a dynamic variable. The total number of taxonomic units contained refers to both vascular and non-vascular flora. The total number of coordinates is higher than the number of coordinates used because the total number contains centroids of MTB and UTM squares as well as centroids of populated places, for which no findings have yet been linked.

It is interesting that of almost one million recorded findings, the largest share of $57 \%$ belongs to the original field observations, which is particularly significant because they are more recent data, compared to $37 \%$ of the findings originating in the literature that are mostly older than a few decades (Fig. 1b). Despite the more or less continuous digitization of herbarium material, the share of geocoded findings from the collections is only $5 \%$, with the emphasis that it is potentially a vast pool of very valuable data still awaiting evaluation. It is a segment that needs increased attention in the coming period. As regards the number of species that have been geocoded, their share given the data source is equal (Fig. 1c).

\section{Dynamics}

Beside the summary of the current cumulative state of individual data types in the FCD, the question is what is the dynamics of their accumulation? Graphs in Fig. 2, which show this aspect, are in principle themselves clear. They relate to the last six years and the first half of 2020. Values are relative (\%) regarding absolute indicators (Fig. 1a). A few facts should be pointed out.
The number of registered users is gradually increasing, as are the number of authors in general, i.e. authors of observations, references, photographs, and other authorized contributions (Fig. 2a). As expected, the number of species and subspecies is generally constant, i.e. the addition of new species is relatively rare and in small numbers compared to the total flora of Croatia. After growth in 2014 2015, the number of synonyms is steady until 2020. The cause is not the nomenclature completion of this aspect of the species description, but the decreased activity in this field, in other words, > 20000 synonyms is only temporary stagnation (Fig. $2 a)$. It is noticeable that the number of coordinates and geocoded sources used from all sources is steadily increasing with a strong jump in 2018 - 2019. (Fig. 2b). The cause is a large number of observations made in FCD in this period, although in fact, these are field observations made in 2016 - 2017. (Fig. 2d). The number of photos in FCD is growing extremely fast (Fig. 2c), from $\sim 52000$ in 2014 to as much as 152000 in the first half of 2020, as well as the number of photographs authors (currently 203). Digitization in five herbarium collections is progressing relatively well (Fig. 2e) with an established growth of about $0.7 \%$ per year, with a total of $~ 27000$ sheets in the six years and with particularly dynamic growth of scanned herbarium sheets, from $<2 \%$ in 2014 to $13 \%$ in 2020. Although this figure looks satisfactory at first glance, with a digitization dynamics of $\sim 4000$ - 4500 sheets per year and about half a million herbarium sheets expected in Croatian collections, the whole process would take $>120$ years, so more attention should be paid to this aspect of the work in the coming period. It is extremely uneven geocoding of herbarium material, depending to a greater extent on external and periodic associates. The total number of geocoded findings and species based on the allegations in the publications increases at a rate of $0.45 \%$ per year (Fig. $2 \mathrm{f}$ ). 
a)

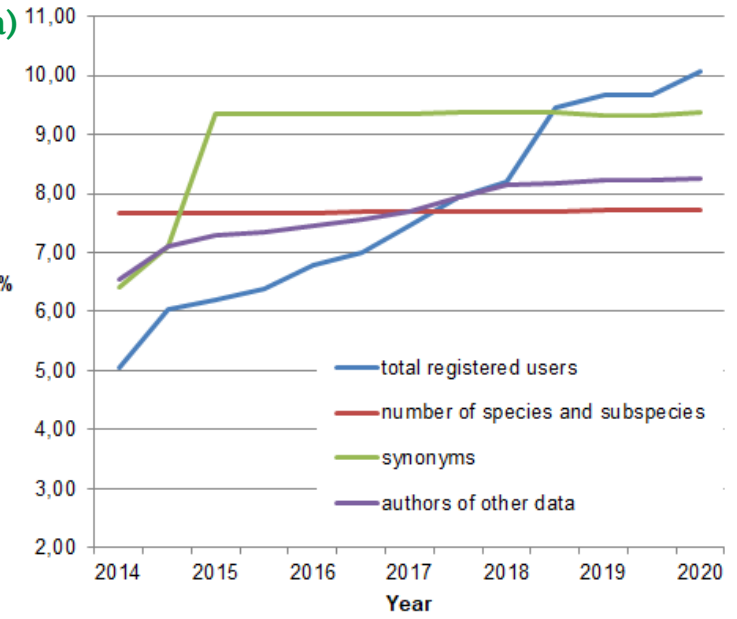

c)

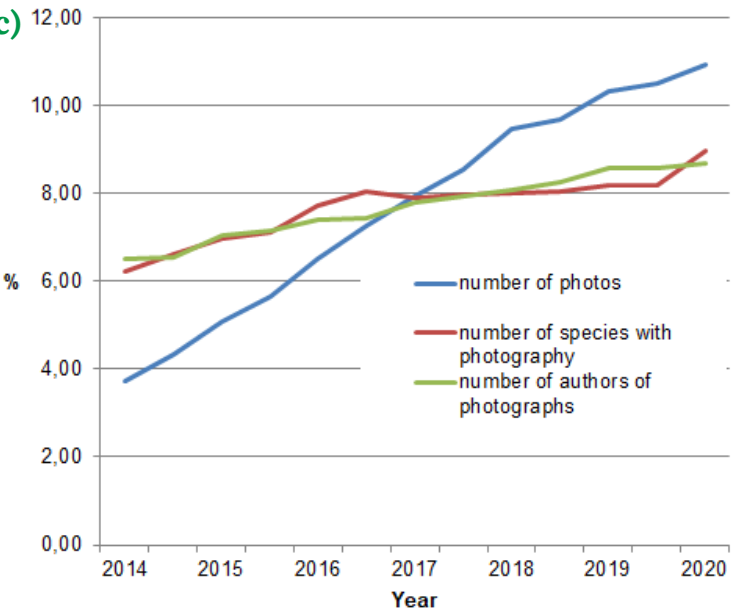

e)

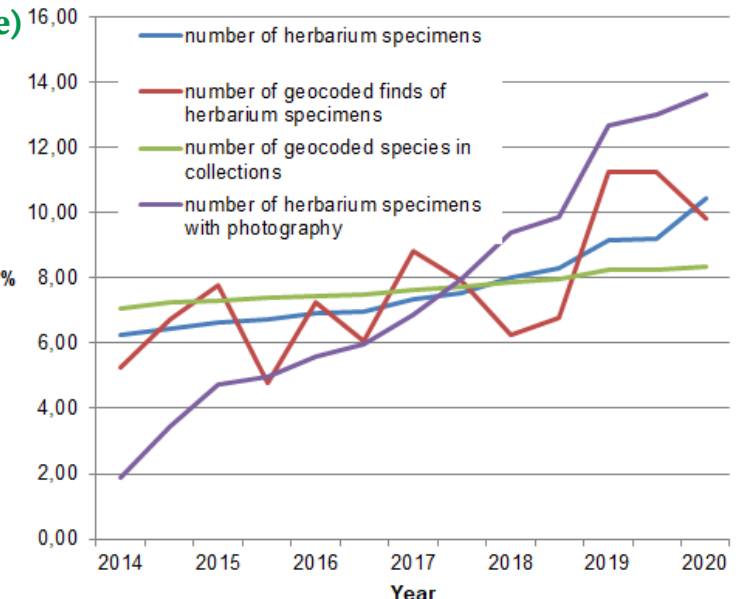

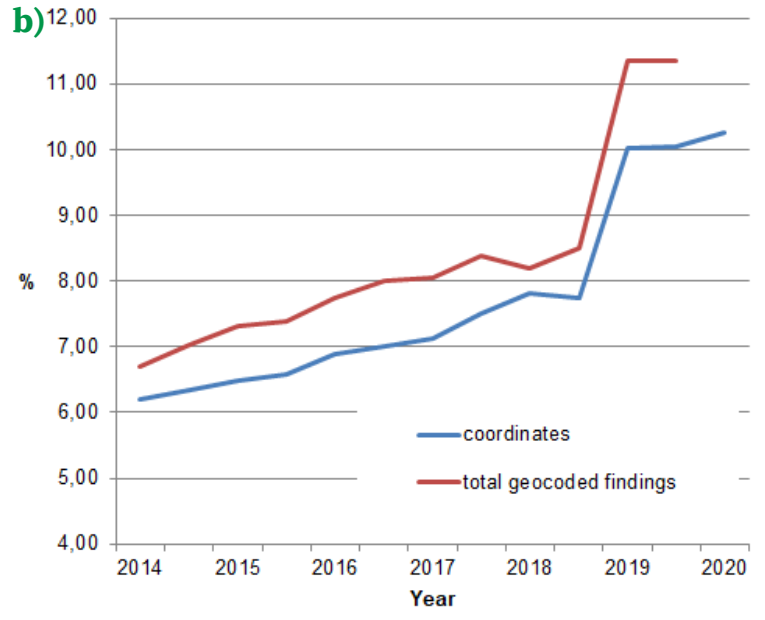
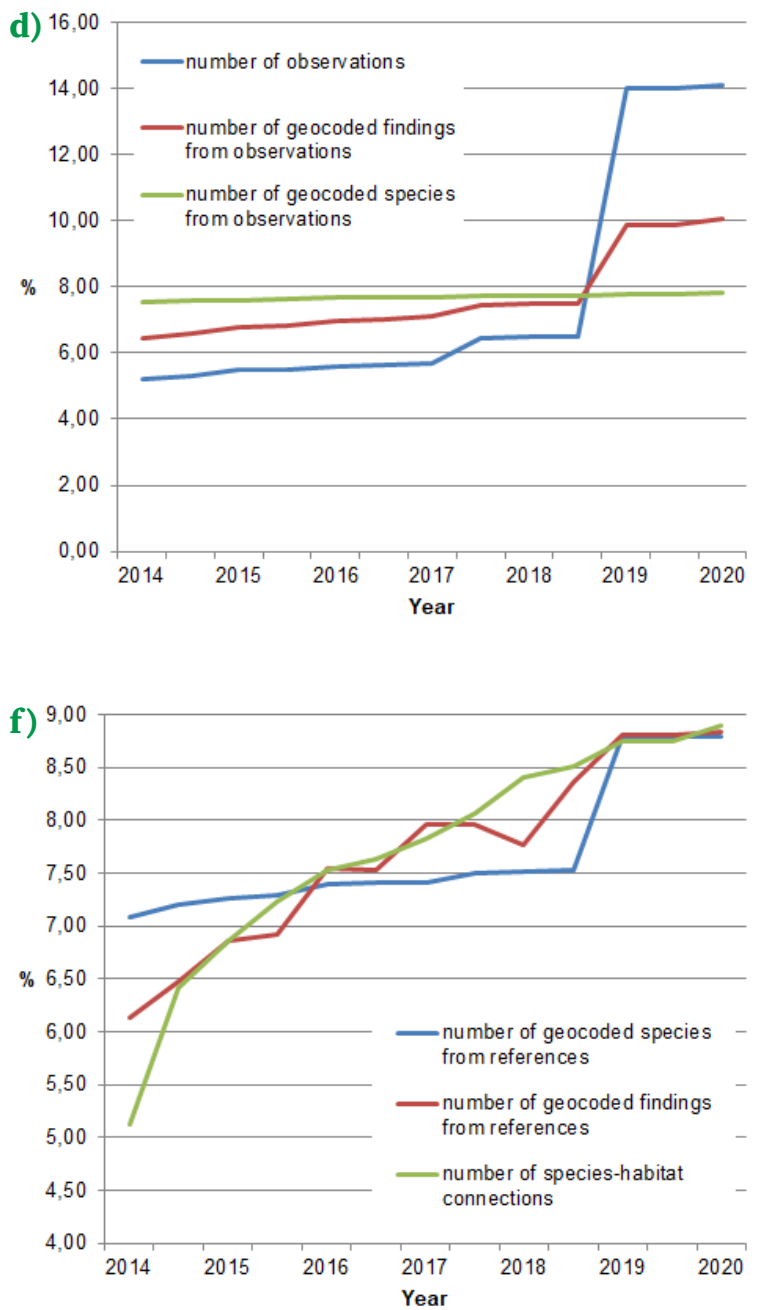

Figure 2. Dynamics of individual FCD indicators (compare legends on graphs a - $f$ ) in shares relative to total figures (applies only to vascular plants). 
a)

$\begin{array}{llllll}\text { year/data } & \text { sesion } & \text { users } & \text { pages } & \text { pages/sesion } & \text { duration sesion (min) } \\ 2015 & 54405 & 21861 & 933221 & 34,31 & 28,14 \\ 2016 & 50643 & 16976 & 963555 & 38,04 & 29,7 \\ 2017 & 50239 & 16256 & 847592 & 33,87 & 27,88 \\ 2018 & 48829 & 16898 & 768801 & 31,07 & 23,97 \\ 2019 & 49783 & 16830 & 744475 & 30,06 & 24,48 \\ \text { Average per year } & 50779,80 & 17825,40 & 851528,80 & 33,47 & 26,83\end{array}$

b)

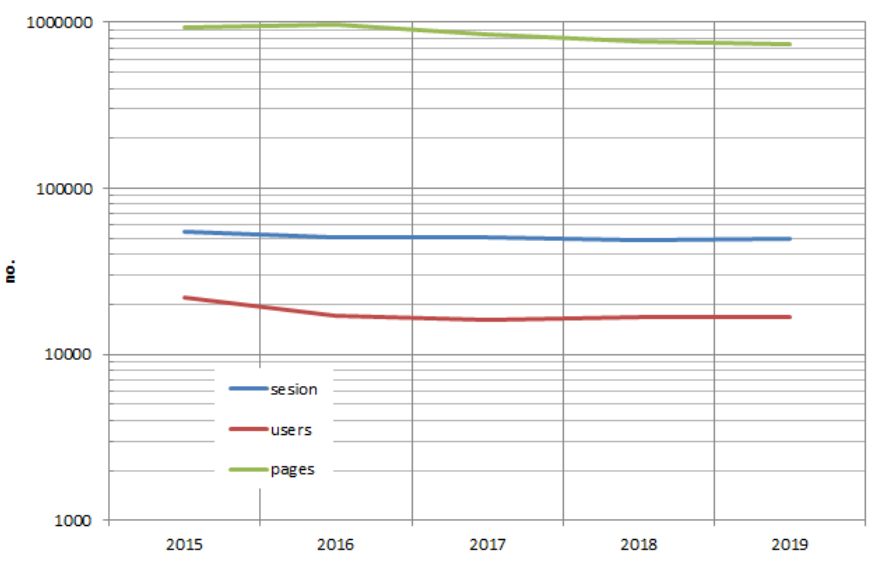

d)

- Users

400

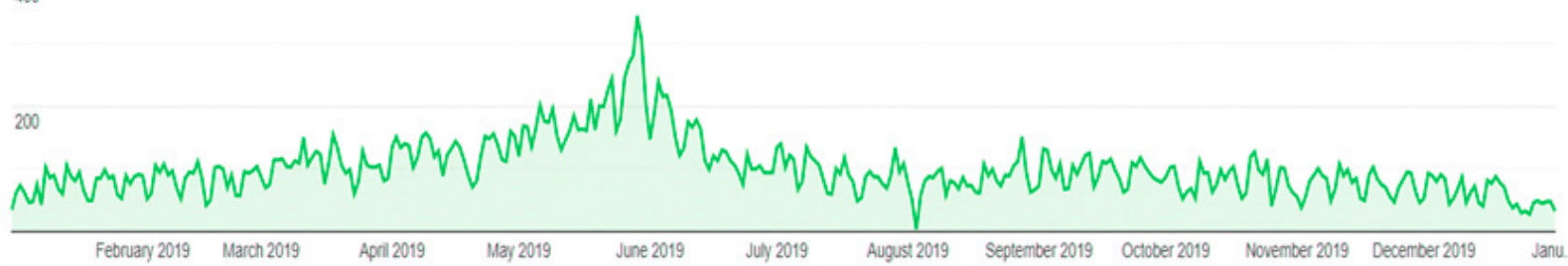

c)

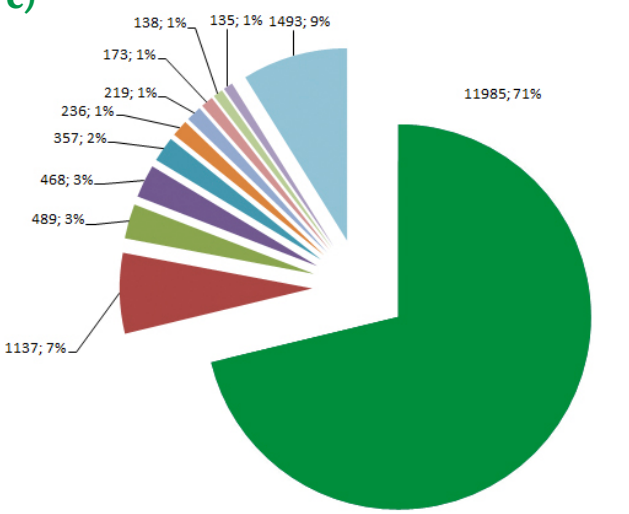

- Croatia - United States - German Slovenia

Bosnia \& Herzegovina - Serbia - Italy

- Italy

Montenegro

Figure 3. Usage dynamics and geographical origin of queries: basic traffic indicators for the period 2014-2019 (a), graphical representation of the number of sessions, users and viewed FCD pages for the same period (b), illustration of the annual usage dynamics for 2019 with weekly dynamics of the number of users (c), display of the number of queries with respect to country of origin (d).

\section{Usage}

What is the use intensity of the FCD and its content and how much data is required and used? Since 2004, FCD has been fully internet-oriented, and the targeted monitoring of access to websites will provide an answer to these questions.
Over the past five-year period (2015 - 2019), the FCD has accessed an average per year of almost 18000 users (recurring and new) who have achieved around 50000 sessions with nearly one million FCD pages viewed and average retention of $26 \mathrm{~min}$ (Fig. 


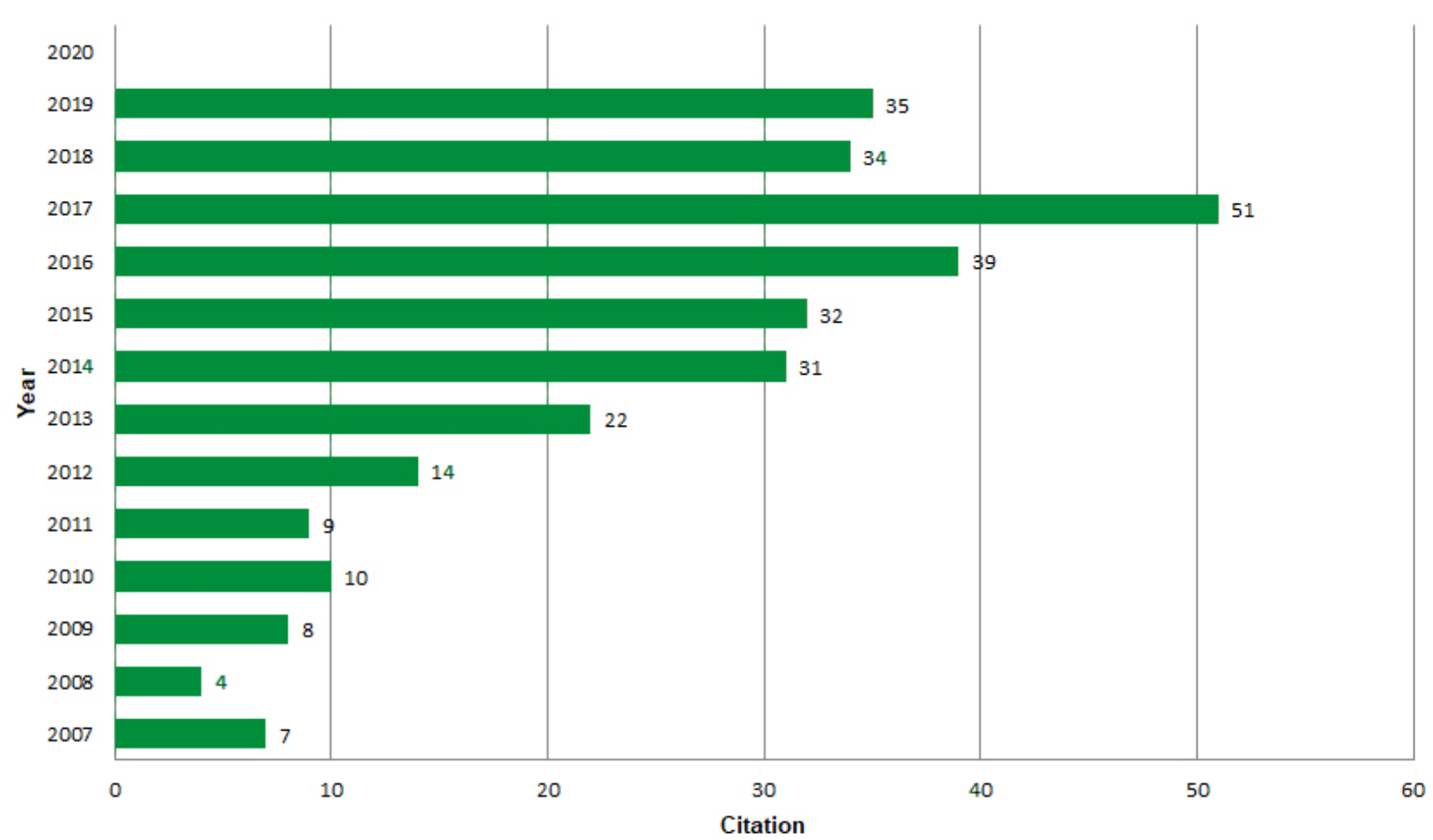

Figure 4. Number of FCD citations in professional and scientific literature for the period 2007 - 2019 according to Google Scholar (November 2020 data).

3a). These figures are very stable during this period, indicating the persuasiveness of use (Fig. 3b). For example, the annual dynamics for 2019 indicate that weekly activity is concentrated on working days, with the increased use of the pre-summer period and a decline in the summer period. It is important to point out that FCD reaches 100 - 350 users per day (Fig. 3c).

Given the country of origin of the inquiry, the expected greatest use is related to the region, with the dominance of inquiries from Croatia (71\%), followed by $\mathrm{BiH}(6.6 \%)$, Serbia (2.7\%), etc., but with a non-negligible number of inquiries originating in the USA, Germany, Italy, etc. (Fig. 3d).

Another indicator - citation, points to the use of FCD in science. The number of FCD citations in the professional and scientific literature in the period 2007 - 2020 according to the Google Scholar search engine is 324 with the time dynamics shown in Fig. 4.
The data accumulated in FCD were also used for the production of a number of basic national works, such as the production of the Red Book (Nikolić and Topić 2005), overview od orchids (Kranjčev 2005), the detection of the Important Plant Area (Nikolić et al. 2010), the review and analysis of endemism (Nikolić et al. 2015) or the production of Flora of Croatia (Nikolić 2020a, 2020b, 2020c). Quotes of these and similar works are actually indirectly quoted by FCD as the source of part of the data contained.

\section{Future}

There are several challenges ahead for FCD in the coming period. They can be classified into three main groups:

\section{Maintenance}

1.1 HD upgrade and maintenance of main and peripheral equipment

1.2 SW upgrades in all segments 


\section{Data entry}

2.1 Continuation of existing activities with efforts to increase dynamics especially in terms of digitization of herbar collections

2.2 Expansion of taxonomic coverage on allocht honous flora and in particular addition and adequate processing of the Protista kingdom

\section{Development}

3.1 Further development of spatial data analysis system using the latest technologies

3.2 Integration of analytical flora with keys for determination

3.3 Adaptation to new mobile communication trends

What is not mentioned in this list is the constant effort to find funds for continuous and smooth work. With the existing achievements of FCD, especially those that are yet to come, there is almost no doubt that the impact on popularization, education, profession and science will continue to have an upward trajectory.

\section{Acknowledgements}

I would like to thank all the associates who have diligently stacked layer by layer of FCD data in the past decades and enabled this database to be what it is today. Without their efforts and knowledge, FCD would be a ,dead letter on paper“. Colleagues from the Faculty of Electrical Engineering and Computing often did more than agreed. For that, thank them, especially to dr. Boris Milašinović.

\section{Literature}

Anonymus (1995): FLOREIN, Interaktive Programm zur Bearbeitung floristischer Daten, Version 4.1. Benutzerhandbuch. Zentralstelle für die Floristische Kartierung Deutschlands. Regensburg.
Antonić, O., Kušan V., Bakran-Petricioli, T., Alegro, A. L., Gottstein Matočec, S., Peternel, H., Tkalčec, Z. (2005): Klasifikacija staništa Republike Hrvatske (Habitat classification of the Republic of Croatia). Drypis, časopis za primjenjenu ekologiju 1(1): 2.

APG - Angiosperm Phylogeny Group (2009): An update of the Angiosperm Phylogeny Group classification for the orders and families of flowering plants: APG III. Botanical Journal of the Linnean Society 161(2): 105-121.

APG - Angiosperm Phylogeny Group (2016): An update of the Angiosperm Phylogeny Group classification for the orders and families of flowering plants: APG IV. Botanical Journal of the Linnean Society 181(1): 1-20.

Ball-Damerow, J. E., Brenskelle, L., Barve, N., Soltis, P. S., Sierwald, P., Bieler, R., LaFrance, R., Ariño, A. H., Guralnick, R. P. (2019): Research applications of primary biodiversity databases in the digital age. PloS one 14(9): e0215794.

Beaman, R., Cellinese, N. (2012): Mass digitization of scientific collections: New opportunities to transform the use of biological specimens and underwrite biodiversity science. ZooKeys 209: 7-17.

Berendsohn, W. G. (1997): A taxonomic information model for botanical databases: the IOPI model. Taxon 46: 283-308.

Boršić, I., Milović, M., Dujmović, I., Bogdanović, S., Cigić, P., Rešetnik, I., Nikolić, T., Mitić, B. (2008): Preliminary check-list of invasive alien plant species (IAS) in Croatia. Natura Croatica 17(2): 55-71.

Brummitt, R. K., Powell, C. E. (1992): Authors of plant names. Royal Botanic Garden, Kew.

Cook, F. E. M. (1995): Economic Botany Data Collection Standard. Prepared for the International Working Group on Taxonomic Databases for Plant Sciences (TDWG). Royal Bot. Gardens, Kew. Crovello, T. J., MacDonald, R. D. (1974): Index of EDP-IR projects in systematics. Taxon 19: 63-76. 
Dallwitz, M. J., Paine, T. A., Zurcher, E. J. (1993): User's guide to the DELTA System: a general system for processing taxonomic descriptions. 4th edition (URL http://delta-intkey.com).

Dallwitz, M. J., Paine, T. A., Zurcher, E. J. (1999): User's guide to the DELTA Editor (URL http:// delta-intkey.com).

Dallwitz, M. J., Paine, T. A., Zurcher, E. J. (2000 onwards): Principles of interactive keys (URL: http://delta-intkey.com).

Đurašević V. (2016): Programska podrška za generiranje dihotomskog identifikacijskog ključa. Diplomski rad, Sveučilište u Zagrebu, Fakultet elektrotehnike i računarstva.

Fertalj, K., Nikolić, T., Helman, T., Mornar, V., Kalpić, D. (2000a): Flora Croatica Database Application. In Anonymus: Mathematics and Computers in Modern Science. Acoustics and Music, Biology and Chemistry, Bussiness and Economics. World Scientific and Engineering Society Press, 175-182.

Fertalj, K., Nikolić, T., Helman, T., Mornar, V., Kalpić, D. (2000b): Flora Croatica Database Application. In Mastorakis, N. ed.: Proceedings of 2000 WSES International Conference on Mathematics and Computers in Biology and Chemistry (MCBC 2000), Montego Bay, Jamaica: World Scientific and Engineering Society, 951-957.

Greuter, W., Brummit, R. K., Farr, E., Kilian, N., Kirk, P. M., Silva, P. C. (eds.) (1993): NCU-3. Names in Current Use for Extant Plant Genera. Regnum Vegetabile 129: XXVI, 1-1464.

Heywood, V. H. (1984): Electronic data processing in taxonomy and systematics. In: Allkin, R., Bisby, F. A. (eds.): Databases in systematics, Academic Press, 1-15.

Jury, S. L. (1991): Some recent computer-based developments in plant taxonomy. Botanical Journal of the Linnean Society 106: 121-128.

Kraljević, L. (2017): Web-aplikacija za vizualizaciju rezultata predviđanja nalazišta biljnih vrsta. Diplomski rad, Sveučilište u Zagrebu, Fakultet elektrotehnike i računarstva.
Kranjčev, R. (2005): Hrvatske orhideje. Prilozi za hrvatsku floru / Croatian Orchids. AKD, Agencija za komercijalnu djelatnost d.o.o., Zagreb.

Lindacher, R. (1995): PHANART, Datenbank der Gefässpflanzen Mitteleuropas. Erklärung der Kennzahlen, Aufbau und Inhalt. Veröff. Geobot. Inst. ETH, Stiftung Rübel, Zürich, 125: 3-436.

Mihelj, D., Fertalj, K., Nikolić, T., Pokupec, A. (2007): Database for plant collection data in Zagreb botanical garden. In: Puchalski, J. (ed.): The 2nd International Conference of Eastern and Central Europaen Botanic Garden - EastCentGard II. "European botanic gardens together towards the implementation of plant conservation strategies". Warszaw/Rogów: Académie Polonaise des Sciences, 49-50.

Milašinović, B., Nikolić, T., Fertalj, K. (2012): An Object Model for Biodiversity Analysis. In: Anderson, D., Yang, H.-J., Varacha, P. (eds.): Latest Trends in Information Technology (Recent Advances in Computer Engineering Series 7). WSEAS Press, 273-278.

Milašinović, B., Nikolić, T., Fertalj, K. (2013): Biodiversity analysis supporting species-subspecies uncertainty in findings data. International journal of biology and biomedical engineering 4: 127-134.

Mitić, B., Boršić, I., Dujmović, I., Bogdanović, S., Milović, M., Cigić, P., Rešetnik, I., Nikolić, T. (2008): Alien flora of Croatia: proposals for standards in terminology, criteria and related database. Natura Croatica 17(2): 73-90.

Nikolić, T. (ed.) (2005-onwards): Flora Croatica Database.. University of Zagreb, Faculty of Science, Department of Botany and Botanical Garden, Zagreb.http://hirc.botanic.hr/fcd (accessed: November 13, 2020).

Nikolić, T., Topić, J. Vuković, N. (eds.) (2010): Botanički važna područja Hrvatske. Prirodoslovno-matematički fakultet Sveučilišta u Zagrebu i Školska knjiga d.o.o., Zagreb.

Nikolić, T. (2020a): Flora Croatica - vaskularna flora Republike Hrvatske, Volumen 1. Uvodni dijelovi, sinopsis porodica, opće kazalo, literatura i dr. Alfa d. d., Zagreb. 
Nikolić, T. (2020b): Flora Croatica - vaskularna flora Republike Hrvatske, Volumen 2. Ključevi za determinaciju s pratećim podatcima: Equisetidae, Lycopodiidae, Ophyoglossidae, Polypodidae, Cycadidae, Ginkgooidae, Gnetidae, Pinidae, Magnoliidae - porodice A-FAB. Alfa d. d., Zagreb. Nikolić, T. (2020c): Flora Croatica - vaskularna flora Republike Hrvatske, Volumen 3. Ključevi za determinaciju s pratećim podatcima: Magnoliidae - porodice FAG-ZYG. Alfa d. d., Zagreb.

Nikolić, T. (ed.) (1994): Popis flore Hrvatske, 1. dio. Flora Croatica. Index Florae Croaticae. Pars 1. Natura Croatica 3 (Suppl. 2.): 1-116.

Nikolić, T. (ed.) (1997): Popis flore Hrvatske, 2. dio. Flora Croatica. Index Florae Croaticae. Pars 2. Natura Croatica 6 (Suppl. 1): 1-232.

Nikolić, T. (ed.) (2000): Popis flore Hrvatske, 3. dio. Flora Croatica. Index Florae Croaticae. Pars 3. Natura Croatica 9 (Suppl. 1): 1-324.

Nikolić, T., Fertalj, K., Helman, T., Mornar, V., Kalpić, D. (2001): CROFlora, a Database Application to Handle Croatian Vascular Flora. Acta Botanica Croatica. 60(1): 31-48.

Nikolić, T., Milašinović, B. (2014): Prostorni profil svojti i analiza raznolikosti u sklopu Flora Croatica baze podataka. Glasnik Hrvatskog botaničkog društva 2(1): 16-22.
Nikolić, T., Milašinović, B., Radović, A., Temunović, M., Grgurev, M. (2014): Repozitorij prostornih podataka u sklopu Flora Croatica baze podataka. Glas. Hrvat. bot. druš. 2(1): 22-23.

Nikolić, T., Milović, M., Bogdanović, S., Jasprica, N. (2015): Endemi u hrvatskoj flori. Alfa d. d., Zagreb.

Nikolić, T., Rešetnik, I. (2007): Plant uses in Croatia. Phytologia Balcanica 13(2): 229-238.

Nikolić, T., Topić, J. (eds.) (2005): Red Book of Vascular Flora of Croatia. Ministry of Culture, State Institute for Nature Protection, Zagreb.

Perović, V. (2016): Primjena statističkih modela u predviđanju nalazišta biljnih vrsta. Graduate thesis. Faculty of Electrical Engineering and Computing, University of Zagreb.

Sugden, A., Pennisi, E. (2000): Diversity Digitized. Science 289 (5488): 2305.

Sullivan, B. L., Aycrigg, J. L., Barry, J. H., Bonney, R. E., Bruns, N., Cooper, C. B. (2014): The eBird enterprise: an integrated approach to development and application of citizen science. Biological Conservation 169: 31-40.

Štimac, I. (2012): Pocket FCD. Tehnička dokumentacija Verzija 0.5. Graduate thesis. Faculty of Electrical Engineering and Computing, University of Zagreb. 